\title{
PEMIKIRAN DAN PERADABAN ISLAM DI NUSANTARA
}

\section{NI'MATUN NAJAH}

\section{A. Latar Belakang}

Sejarah menempati urutan terpenting terhormatnya suatu bangsa oleh penduduknya sendiri suatu bangsa yang bermartabat tinggi penduduknya dipastikan harus mengetahui seridaknya sejarah nasional bangsanya sendiri.

Agama juga merupakan unsur terpenting dalam keyakinan hidup manusia. Agama yang diyakini para penduduk tidaklah hanya satu akan tetapi bermacam-macam dimana agama tersebut memiliki sejarah besar sejak proses masuknya sampai proses berkembangnya sampai sekarang.

Harus kita tahu Islam adalah salah satu agama besar di dunia dengan pengikut terbanyak. Perkembangan Islam di penjuru dunia berkembang pesat sejak adanya Islam pertama kali walaupun awal mausknya sempat mengalami jatuh bangun dalam perkembanganya.

Setelah wafatnya Nabi Muhammad SAW pada tahun $632 \mathrm{M}$ atau $10 \mathrm{H}$, selanjutnya kepemimpinan Islam dipegang oleh para khalifah. Dibawah kepemimpinan para khalifah, agama Islam mulai disebarkan lebih luas lagi ke berbagai penjuru. Sampai abad ke-8 saja, pengaruh Islam telah menyebar ke seluruh Timur Tengah, Afrika Utara, dan Spanyol. Kemudian pada masa dinasti Ummayah pengaruh Islam mulai berkembang hingga Nusantara. 
Sejarahpun mencatat, kepulauan-kepulauan di Nusantara merupakan daerah-daerah yang terkenal sebagai penghasil rempah-rempah terbesar di dunia. Hal tersebut membuat banyak para pedagang dari berbagai penjuru dunia datang ke Nusantara untuk membeli rempah-rempah yang akan dijual kembali ke daerah asal mereka. Termasuk para pedagang dari Arab, Persia, dan Gujarat. Selain berdagang, para pedagang muslim yang dating ke Nusantara juga berdakwah untuk mengenalkan agama Islam kepada penduduk lokal.

Islam merupakan salah satu agama yang masuk dan berkembang di Indonesia. Hal ini tentu bukanlah sesuatu yang asing, Agama Islam masuk ke Indonesia dimulai dari daerah pesisir pantai,kemudian diteruskan ke daerah pedalaman-pedalaman oleh para ulama atau penyebar ajaran Islam.

\section{A. Teori Tentang Masuknya Islam ke Indonesia}

\section{Teori Pertama}

Teori yang tergolong lebih awal, karena itu disebut saja teori pertama, ialah teori Christian Snouck Hurgronje, seorang orientalis terkemuka asal Belanda. Teorinya itu dikemukakan dalam tulisannya "De Islam in NederlandschIndie". Teori yang diramu berdasarkan atas sejumlah sumber, seperti tulisan-tulisan pada batu nisan dan dari beberapa catatan perjalanan, antara lain yang di buat oleh seorang Vanezia bernama Marcopolo dalam abad ke-13 dan oleh seorang Arab bernama Ibn Batutah dalam abad ke14 pada prinsipnya menyatahkan bahwa proses Islamisasi Indonesia mulai berlangsung kira-kira setengah abad sebelum kota Bagdad ditaklukkan oleh raja Mongol Hulagu pada tahun $1258 \mathrm{M}$. teori ini selanjutnya menegaskan bahwa tidak ada kekuasaan Negara yang campur tangan dalam proses tersebut. Pengislaman atas masyarakat pantai di pulau-pulau Sumatera, Jawa, Kalimantan, Sulawesi, dan pulau-pulau kecil lainnya, semata- mata adalah usaha saudagar-saudagar muslim dan para penetap dari negara-negara di India Muka. Mereka merupakan pedagang- pedagang tradisional yang sejak sebelum kedatangan agama Islam telah menjalin hubungan perdagangan dari India ke pulau-pulau Nusantara. Orang-orang India yang telah muslim itu kemudian turut mengambil bagian dalam kehidupan penduduk Nusantara.

Dapat disimpulkan dari teori ini bahwa; Pertama, proses Islamisasi di Indonesia mulai berlangsung sejak awal abad ke-13 M. Kedua, Islam datang ke Indonesia tidak langsung dari Arab melainkan lewat India. Ketiga, proses Islamisasi itu terjadi melalui perkawinan dan penaklukan. Selanjutnya teori ini ternyata kemudian memperoleh dukungan dari para 
pakar Barat, terutama dikalangan sarjana Belanda dengan penambahan pembuktian dan argumentasi di sana-sini. ${ }^{1}$

\section{Teori Kedua}

Teori kedua ini sebenarnya lahir sebagai reaksi terhadap teori pertama. Beberapa para ahli secara sendiri-sendiri meragukan hasil penemuan Snouck, terutama yang menyangkut tiga permasalahan pokok di atas. Mereka mengajukan sejumlah bukti dan argumentasi secara fragmentaris, maka muncullah yang kita sebut teori kedua. Berdasarkan berita-berita Cina yang berasal dari abad ke-7 M (zaman dinasti Tang) dan sumber-sumber Jepang pada abad ke- $8 \mathrm{M}$, para ahli berpendapat bahwa orang-orang Muslim dari Arab telah datang ke negeri-negeri Melayu, khususnya Sumatera, pada abad ke-7 M.

Perkiraan bahwa Islam telah datang ke pulau- pulau Melayu pada abad ke-7 M, menurut Thomas W. Arnold; di perkuat dengan pengetahuaan tentang adanya perdagangan yang luas dengan dunia Timur yang di lakukan oleh orang-orang Arab sejak masa permulaan sekali. Pada abad ke-2 sebelum Masehi perdagangan dengan Seilon sepenuhnya berada ditangan orang-orang Arab. Pada awal abad ke-7 M, perdagangan dengan Cina melalui Seilon mengalami pertumbuhan dan perkembangan pesat sehingga pada pertengahan abad ke- $8 \mathrm{M}$, sudah banyak orang-orang Arab yang di temui di Kanton, sementara antara abad 10-15 M, hingga datangnya bangsa Portugis, mereka telah merupakan "'Raja-raja”, perdagangan Timur yang sudah mantap.

Wan Husein Azmi, menyatakan bahwa saudagar- saudagar Arab yang mengunjungi Indonesia pada abad ke-7 M, yakni orang-orang Arab dari Yaman dan Oman, adalah saudagar- saudagar Muslim. Keyakinan ini berdasarkan atas sebuah hadits yang menceritakan tentang sahabat Mu'adz bin Jabal yang dikirim Nabi Muhammad saw. ke sana untuk mengajar Qur'an dan hukum- hukum agama Islam. Saudagar-saudagar inilah yang membawa Islam langsung ke Nusantara melalui Lautan Hindia dan juga Laut Cina Selatan.(Baloch, hlm. 24-25, 1980). Rusdi sufi memperkuat keyakinan ini berdasarkan cerita- cerita yang termuat dalam tradisi lokal. Berpegang pada berita- berita dalam 'Hikayat Raja-raja Pasai" dan 'Sejarah Melayu''ia sampai pada kesimpulan bahwa Islam yang masuk ke Indonesia langsung dari Arab, dilakukan oleh Syekh Ismail, seorang perutusan dari Mekah. Prof . Gabril Ferrand dan Prof .Paul Wheatly demikian pula.

\footnotetext{
${ }^{1}$ Rosita Baiti and Abdur Razzaq, “TEORI DAN PROSES ISLAMISASI DI INDONESIA,” 2014, hlm.133-135.
} 
Mereka menyimpulkan bahwa berdasarkan keterangan para musafir dan pedagang Arab, agama Islam itu datang ke Indonesia langsung dari Arab.

Motivasi kedatangan dan proses Islamisasi tersebut mungkin terutama berhubungan dengan faktor ekonomi, yaitu melalui pelayaran dan perdagangan. Namun demikian proses ini dapat pula secara khusus melalui Dakwah Islamiyah yang dilakukan para penyiar (Muballigh) yang kedatanganya dapat bersama-sama dengan para pedagang, atau tersendiri. Sejak abad 13 M. penyebaran Islam melalui Tasawuf termasuk kategori yang berfungsi dan membentuk kehidupan sosial bangsa Indonesia, yang meninggalkan buktibukti yang jelas pada tulisan-tulisan antara abad ke-13 dan $18 \mathrm{M}$. hal yang bertalian langsung dengan penyebaran Islam di Indonesia, memegang suatu peranan dan bagian terpenting dalam organisasi masyarakat kota-kota pelabuhan, dan sifat spesifik Tasawuf yang memudahkan penerimaan masyarakat yang belum Islam kepada lingkungannya. Ahli-ahli Tasawuf Indonesia pada periode ini amat terkenal, seperti: Hamzah Fansuri, ArRaniry, Syamsuddin Al-Samatrani, Syekh Kuala, Syihabuddin dari Palembang, Kemas Fakhruddin, Abdul Al- Samad Al-Falimbani, Syekh Arsyad Banjar, Syekh Nawawi Banten, Syekh Yusuf Makasar dan lain-lain.

Erat kaitannya, dengan proses terjadinya Islamisasi tersebut, maka orang-orang Muslim dapat pula membentuk dan mendirikan Pesantren-pesantren, dan Madrasah-madrasah (jalur pendidikan formal). Melalui kelembagaan di masyarakat tersebut dapat pula disebarkan, dan dikembangkan ke daerah dan lingkunganya, atau ke daerah-daerah di luarnya. $^{2}$

2. Teori Pendukung Masuknya Islam ke Indonesia

a. Teori Gujarat

Teori Gujarat oleh Snouck Hurgronje, menyatakan masuknya Islam berasal dari Gujarat. Snouck Hurgronje menitikberatkan pandangannya ke Gujarat berdasarkan: 1) kurangnya fakta yang menjelaskan peranan bangsa Arab dalam menyebarkan agama Islam ke Nusantara. 2) hubungan dagang Indonesia-India telah terjalin lama. 3) inkripsi tertua tentang Islam terdapat di Sumatera memberikan gambaran antara hubungan antara Sumatera dengan Gujarat. Senada dengan pendapat W.F. Stutterheim, menyatakan masuknya Iskam ke Indonesia berasal dari Gujarat, abad ke-13. Dibuktikan batu nisan Sultan pertama dari Kerajaan Samudra, yakni Malik Al- Saleh wafat tahun 1297 M.

\footnotetext{
${ }^{2}$ Baiti and Razzaq, 136-139.
} 


\section{b. Teori Makkah}

Hamka melahirkan teori baru yaitu Teori Makkah. Hamka menolak pandangan yang menyatakan bahwa agama Islam masuk ke Nusantara abad ke-13 dan berasal dari Gujarat. Hamka lebih mendasarkan pandangannya peranan bangsa Arab, diikuti orang Persia dan Gujarat sebagai pembawa agama Islam ke Indonesia. Gujarat dinyatakan sebagai tempat singgah semata, dan Makkah sebagai pusat, atau Mesir sebagai tempat pengambilan ajaran Islam.

\section{c. Teori Persia}

Menyatakan kebudayaan masyarakat Islam Indonesia mempunyai persamaan dengan Persia, antara lain: a) peringatan 10 Muharram atau Asyura sebagai hari peringatan Syi'ah atas kematian syahidnya Husain. b) adanya kesamaan ajaran antara Syaikh Siti Jenar dengan ajaran Sufi Iran Al-Hallaj. c) penggunaan istilah bahasa Iran dalam sistem mengeja huruf Arab. d) nisan pada makam Malikus Saleh (1297) dan makam Malik Ibrahim (1419) di Gresik dipesan dari Gujarat. Teori Persia mempunyai kesamaan mutlak dengan teori Gujarat. $^{3}$

\section{B. Proses Asimilasi di Indonesia}

1. Perdagangan

Diantara saluran Islamisasi di Indonesia pada taraf permulaannya ialah melalui perdagangan.Hal ini sesuai dengan kesibukan lalu lintas perdagangan abad-7 sampai abad ke-16, perdagangan antara negeri-negeri di bagian barat, Tenggara dan Timur benua Asia dan dimana pedagang-pedagang Muslim (Arab, Persia, India) turut serta menggambil bagiannya di Indonesia. Mengutip pendapat Tome Pires berkenaan dengan saluran islamisasi melalui perdagangan ini dipesisir pulau Jawa, Uka Tjandrasasmita menyebutkan bahwa para pedagang muslim banyak yang tinggal di pesisir pulau Jawa yang penduduknya ketika itu masih belum menganut agama Islam. Mereka berhasil mendirikan mesjid-mesjid dan mendatangkan mullah-mullah dari luar sehingga jumlah mereka menjadi banyak.

\section{Ekonomi}

Dari sudut ekonomi, para pedagang muslim memiliki status sosial yang lebih baik daripada kebanyakan pribumi, sehingga penduduk pribumi, terutama puteri-puteri bangsawan, tertarik untuk menjadi isteri saudagar-saudagar itu. Sebelum menikah, mereka

\footnotetext{
${ }^{3}$ Samsul Munir Amin, Sejarah Peradaban Islam (Jakarta: Amzah, 2009), hal.304.
} 
diislamkan terlebih dahulu. Setelah mereka mempunyai keturunan, lingkungan mereka makin luas. Akhirnya timbul kampung-kampung, daerah-daerah dan kerajaan-kerajaan muslim. Dalam perkembangan berikutnya, ada pula wanita muslim yang dikawini oleh keturunan bangsawan; tentu saja setelah yang terakhir ini masuk Islam terlebih dahulu. Jalur perkawinan ini lebih menguntungkan apabila terjadi antara saudagar muslim dengan anak bangsawan atau anak raja dan anak adipati, karena raja, adipati atau bangsawan itu kemudian turut mempercepat proses islamisasi.

\section{Pendidikan}

Islamisasi juga dilakukan melalui jalur pendidikan ${ }^{4}$, baik pesantren maupun pondok yang diselenggarakan oleh-oleh guru-guru agama, kyai-kyai, dan para ulama. Di pesantren atau pondok itu calon ulama, guru agama dan kyai mendapat pendidikan agama. Setelah keluar dari pesantren, mereka pulang ke kampung masing-masing atau berdakwah ke tempat tertentu mengajarkan Islam. Misalnya, pesantren yang didirikan oleh Raden Rahmat di Ampel Denta di Surabaya, dan Sunan Giri di Giri. Keluaran pesantren Giri ini banyak yang diundang ke Maluku untuk mengajarkan agama Islam. ${ }^{5}$

\section{Kesenian}

Saluran islamisasi melalui kesenian yang paling terkenal adalah pertunjukan wayang. Dikatakan, Sunan Kalijaga adalah tokoh yang paling mahir dalam mementaskan wayang. Dia tidak pernah meminta upah pertunjukan, tetapi ia meminta para penonton untuk mengikutinya mengucapkan kalimat syahadat. Sebagian besar cerita wayang masih dipetik dari cerita Mahabharata dan Ramayana, tetapi di dalam cerita itu disisipkan ajaran dan nama-nama pahlawan Islam. ${ }^{6}$ Selain itu, proses asimilasi melalui jalur ini juga dlakukan oleh Sunan Bonang dan Sunan Drajat lewat kesenian gamelan dan lagu, Sunan Kudus lewat cerita pendek . Melalui jalur-jalur itu, proses Islamaisasi Indonesia terutama di Pulau Jawa mengalami perkembangan yang pesat. Agama Islam hingga kini di anut oleh mayoritas masyarakat Indonesia.

5.Politik

Kekuasaan raja memiliki peranan sangat besar dalam proses Islamisasi. Ketika seorang raja memeluk agama Islam, maka secara tidak langsung biasanya rakyat mengikuti jejak rajanya. Dengan demikian, setelah agama Islam mulai tumbuh di

${ }^{4}$ Faisal Mubarak Seff, "Perkembangan Kebijakan Pendidikan Islam Indonesia," TA 'LIM MUTA 'ALLIM 2, no. I (2014).

5 Dalimunthe Dalimunthe, "Kajian Proses Islamisasi di Indonesia (Studi Pustaka)," Jurnal Studi Agama dan Masyarakat 12, no. 1 (March 20, 2017): hal. 6-8, https://doi.org/10.23971/jsam.v12i1.467.

${ }^{6}$ Badri Yatim, Sejarah peradaban Islam: Dirasah Islamiyah II, 2016, 201-3. 
masyarakat, kepentingan politik dilaksanakan melalui perluasan wilayah kerajaan yang diikuti dengan penyebaran agama. Contohnya, Sultan Demak mengirimkan pasukannya di bawah Fatahillah untuk menduduki wilayah Jawa Barat dan memerintahkan untuk menyebarkan agama Islam. ${ }^{7}$

C.Tahap-Tahap Perkembangan Islam

\section{Kehadiran para pedagang muslim(7-12M)}

Fase ini diyakini sebagai fase permulaan dari proses sosialisasi Islam dikawasan Asia Tenggara, yang dimulai dengan kontak sosial budaya antara pendatang Muslim dengan penduduk setempat.Pada fase pertama ini, tidak ditemukan data mengenai masuknya penduduk asli ke dalam Islam.Bukti yang cukup jelas mengenai hal ini baru diperoleh yakni pada permulaan abad ke-13 M/ 7 H. Sangat mungkin dalam kurunabad ke 1 sampai $4 \mathrm{H}$ terdapat hubungan perkawinan antara pedagang Muslim denganpenduduk setempat, hingga menjadikan mereka beralih menjadi Muslim. Tetapi ini barupada tahap dugaan. Walaupun di Leran - Gresik, terdapat sebuah batu nisan bertuliskanFatimah binti Maimun yang wafat pada tahun 475 H / $1082 \mathrm{M}$. Namun dari bentuknya,nisan itu menunjukkan pola gaya hias makam dari abad ke-16 M seperti yang ditemukandi Campa, yakni berisi tulisan yang berupa do'a-do'a kepada Allah. 2.Terbentuknya Kerajaan Islam ( $13-16 \mathrm{M}$ )

Pada fase kedua ini, Islam semakin tersosialisasi dalam masyarakat Nusantaradengan mulai terbentuknya pusat kekuasaan Islam. Pada akhir abad ke-13 kerajaanSamudera Pasai sebagai kerajaan Islam pertama di Indonesia merebut jalur perdagangandi Selat Malaka yang sebelumnya dikuasai oleh kerajaan Sriwijaya. Hal ini terusberlanjut hingga pada permulaan abad ke-14 berdiri kerajaan Malaka di SemenanjungMalaysia.Sultan Mansyur Syah (w. 1477 M) adalah sultan keenam Kerajaan Malakayang membuat Islam sangat berkembang di Pesisir timur Sumatera dan Semenanjung Malaka.Di bagian lain, di Jawa saat itu sudah memperlihatkan bukti kuatnya peranan kelompok masyarakat Muslim.

\section{Pelembagaan Islam}

Pada fase ini sosialisasi Islam semakin tak terbendung lagi masuk ke pusat-pusat kekuasaan, merembes terus sampai hampir ke seluruh wilayah.Hal ini tidak bisa dilepaskan dari peranan para penyebar dan pengajar Islam.Mereka menduduki berbagai jabatan dalam struktur birokrasi kerajaan, dan banyak diantara mereka menikah

\footnotetext{
${ }^{7}$ Baiti and Razzaq, "TEORI DAN PROSES ISLAMISASI DI INDONESIA,” 144.
} 
denganpenduduk pribumi. Dengan kata lain, Islam dikukuhkan di pusat-pusat kekuasaan diNusantara melalui jalur perdagangan, perkawinan dengan elit birokrasi dan ekonomi, disamping dengan sosialisasi langsung pada masyarakat bawah. Pengaruh islamisasi yangpada awalnya hanya berpusat di satu tempat telah jauh meluas ke wilayah-wilayah lain di asia tenggara. ${ }^{8}$

\section{Sejarah Pendidikan Bahasa Arab di Indonesia}

Sejauh ini belum ada hasil penelitian yang memastikan sejak kapan studi bahasa Arab di Indonesia mulai dirintis dan dikembangkan. Asumsi yang selama ini berkembang adalah bahwa bahasa Arab sudah mulai dikenal oleh bangsa Indonesia sejak Islam dikenal dan dianut oleh mayoritas bangsa kita. Jika Islam secara meluas telah dianut oleh masyarakat kita pada abad ke-13, maka usia pendidikan bahasa Arab dipastikan sudah lebih dari 7 abad. Karena perjumpaan umat Islam Indonesia dengan bahasa Arab itu paralel dengan perjumpaannya dengan Islam. Dengan demikian, bahasa Arab di Indonesia jauh lebih "tua dan senior" dibandingkan dengan bahasa asing lainnya.

Sejak sekutu menjajah negara kita, banyak mahasiswa Indonesia yang melanjutkan di beberapa perguruan tinggi di Timur Tengah. Mereka mempelajari bahasa Arab bukan hanya sebagai alat mempelajari Islam tetapi memang benar-benar ingin mempelajari bahasa Arab, sehingga mereka menjadi ahli-ahli di bidang bahasa Arab dan mampu berbahasa Arab secara aktif. Mereka melakukan pembaruan metode pengajaran bahasa Arab sehingga bahasa Arab dapat disebarluaskan dan berkembang di Indonesia, Mereka akhirnya berhasil membentuk ahli-ahli bahasa Arab dan menghasilkan alumni yang mampu menggunakan bahasa Arab aktif untuk berkomunikasi. Dan akhirnya para ahli bahasa arab di Indonesia akhirnya terdorong untuk segera mengajarkan bahasa Arab melalui metode terbaru dan paling sesuai ${ }^{10}$.

Pembelajaran dan pendidikan bahasa Arab mulai berkembang seiring perkembangan zaman dan ilmu pengetahuan. Banyak Perguruan Tinggi mulai membuka prodi-prodi dan jurusan-jurusan bahasa Arab baik bidang linguistik, sastra, terjemah, bahkan kebudayaan

\footnotetext{
8 Artika Sastra Wahyuni and Eza Syafri Rahmadhani, "SEJARAH PERADABAN ISLAM TEORI MASUKNYA ISLAM KE-NUSANTARA," https://www.researchgate.net/publication/338066708_SEJARAH_PERADABAN_ISLAM.

${ }^{9}$ Nurul Hanani, "Prospek Pendidikan Bahasa Arab di Indonesia Pada Era Perkembangan Zaman," Didaktika Religia 4, no. 2 (August 3, 2016): 23-38, https://doi.org/10.30762/didaktika.v4.i2.p23-38.2016.

تكنولجيا التعليم ودوره في تعليم اللغة العربية للناطقين بلغة أخرى," “ سـانـ (LISANUNA): Jurnal Ilmu Bahasa Arab Dan Pembelajarannya 9, no. 2 (2020): 15568.
} 
Arab, khususnya perguruan tinggi-perguruan tinggi Islam. Selain Perguruan Tinggi. banyak madrasah-madrasah juga mulai memasukkan bahasa Arab sebagai mata pelajaran yang diajarkan kepada para siswa. Pembelajaran bahasa Arab sebagai keterampilan daripada ilmu pengetahuan. Karena tujuannya adalah pembelajar mampu menggunakan bahasa Arab baik lisan maupun tertulis dengan baik dan benar ${ }^{11}$

Para ahli bahasa Arab juga selalu mengembangkan berbagai metode, media, strategi pengajaran bahasa Arab, sehingg bahasa Arab lebih mudah diserap, diterima, dan dipahami oleh masyarakat. Mereka melakukan berbagai penelitian. Pembentukan lembaga-lembaga khusus bahasa Arab yang bertujuan untuk meningkatkan kualitas bahasa Arab di Indonesia dan menyebarluaskannya di kalangan masyarakat. ${ }^{12}$

${ }^{11}$ Ahmad Muradi and Faisal Mubarak Seff, "HIGHER ORDER THINKING SKILLS DALAM KOMPETENSI DASAR BAHASA ARAB," Arabi: Journal of Arabic Studies 5, no. 2 (n.d.): $177-90$.

12 Setya Rini, "Perkembangan Bahasa Arab Di Indonesia," Kompasiana (blog), n.d., https://www.kompasiana.com/arin12/5c0e69dc677ffb68b8081174/perkembangan-bahasa-arab-di-indonesia. 


\section{BAB III}

\section{PENUTUP}

\section{A. KESIMPULAN}

Proses Islamisasi di Indonesia menurut teori pertama, mulai berlangsung sejak awal abad ke-13 M. dan menurut teori kedua, sejak abad ke-7 M. sampai abad ke- 15. Adapun teori pendukung dari teori pertama dan kedua adalah teori Gujarat, teori Makkah dan teori Persia.

Ada beberapa proses asimilasi di Indonesia di antaranya; saluran perdagangan, Kesibukan lalu lintas perdagangan abad ke-7. Membuat pedagang-pedagang muslim (Arab, Persia, dan India) turut ambil bagian di Indonesia. Dari sudut ekonomi, para pedagang muslim memiliki status sosial yang lebih baik daripada kebanyakan pribumi, sehingga penduduk pribumi, terutama puteri-puteri bangsawan, tertarik untuk menjadi isteri saudagarsaudagar itu. Sebelum kawin, mereka diislamkan lebih dahulu. Islamisasi juga dilakukan melalui pendidikan, baik pesantren maupun pondok. Saluran islamisasi melalui kesenian, dilakukan dengan pertunjukan wayang,gemelang dan lagu. Jalur Politik, Kekuasaan raja memiliki peranan sangat besar dalam proses Islamisasi.

Tahap-Tahap Perkembangan Islam; 1) Kehadiran para pedagang muslim(7 - 12M). 2) Terbentuknya Kerajaan Islam ( 13 - 16 M). 3) Pelembagaan Islam.

bahasa Arab sudah mulai dikenal oleh bangsa Indonesia sejak Islam dikenal dan dianut oleh mayoritas bangsa kita. Jika Islam secara meluas telah dianut oleh masyarakat kita pada abad ke-13, maka usia pendidikan bahasa Arab dipastikan sudah lebih dari 7 abad. 
Pembelajaran dan pendidikan bahasa Arab mulai berkembang seiring perkembangan zaman dan ilmu pengetahuan ${ }^{13}$.

${ }^{13}$ Faisal Mubarak Seff, "Implementatiton of The Direct Methods in Muhadatsah Learning at Antasari State Islamic University,” n.d. 


\section{DAFTAR PUSTAKA}

Baiti, Rosita, and Abdur Razzaq. "TEORI DAN PROSES ISLAMISASI DI INDONESIA," 2014, 13.

Dalimunthe, Dalimunthe. "Kajian Proses Islamisasi di Indonesia (Studi Pustaka)." Jurnal Studi Agama dan Masyarakat 12, no. 1 (March 20, 2017): 115-25. https://doi.org/10.23971/jsam.v12i1.467.

Hanani, Nurul. "Prospek Pendidikan Bahasa Arab di Indonesia Pada Era Perkembangan Zaman." Didaktika Religia 4, no. 2 (August 3, 2016): 23-38. https://doi.org/10.30762/didaktika.v4.i2.p23-38.2016.

Mubarak Seff, Faisal. "Implementatiton of The Direct Methods in Muhadatsah Learning at Antasari State Islamic University," n.d.

. "Perkembangan Kebijakan Pendidikan Islam Indonesia." TA'LIM MUTA'ALLIM 2, no. I (2014).

(LSANUNA): Jurnal Ilmu Bahasa Arab Dan Pembelajarannya 9, no. 2 (2020): 155-68.

Muradi, Ahmad, and Faisal Mubarak Seff. "HIGHER ORDER THINKING SKILLS DALAM KOMPETENSI DASAR BAHASA ARAB." Arabi: Journal of Arabic Studies 5, no. 2 (n.d.): 177-90.

Rini, Setya. "Perkembangan Bahasa Arab Di Indonesia." Kompasiana (blog), n.d. https://www.kompasiana.com/arin12/5c0e69dc677ffb68b8081174/perkembanganbahasa-arab-di-indonesia.

Samsul Munir Amin. Sejarah Peradaban Islam. Jakarta: Amzah, 2009.

Wahyuni, Artika Sastra, and Eza Syafri Rahmadhani. "SEJARAH PERADABAN ISLAM TEORI MASUKNYA ISLAM KE-NUSANTARA," n.d. https://www.researchgate.net/publication/338066708_SEJARAH_PERADABAN_IS LAM.

Yatim, Badri. Sejarah peradaban Islam: Dirasah Islamiyah II, 2016. 